\title{
Comparing the Effects of L2-based with Code- switching-based Instruction on EFL Speaking Classes
}

\author{
Dwi Ide Rahayu \\ Yogyakarta State University, Indonesia \\ Margana \\ Yogyakarta State University, Indonesia
}

\begin{abstract}
This study is aimed at investigating the effects of L2-based and code-switching-based instruction in teaching Indonesian EFL primary level speaking classes by comparing and examining any potential correspondences between the uses of two different instructions with students' improved speaking achievement. The participant of the study consisted of 70 seventh grade students at a Junior High School in Central Java Province, Indonesia. The samples were divided into two groups: experimental and control group. The former was taught using L2-based-instruction (L2BI) and the later was taught using the most common instruction used i.e. code-switching-based-instruction (CBI). A speaking performance test was developed by the researcher and administered before and after the experiment as pre-test and post-test. The data was analyzed using Analysis of Variance (ANOVA). The finding of the study revealed significant differences $(0 \alpha 05)$ between the groups in support of the experimental group.
\end{abstract}

Index Terms-L2-based instruction (L2BI), code-switching-based instruction (CBI), speaking, primary level EFL

\section{INTRODUCTION}

The language as medium of instruction in 'English as a Foreign Language' (EFL) classrooms such as in Indonesia has long been a subject of debate, where there have been supporters of English-Only class to promote an authentic language use and on the other hand there also have been supporters of code-switching-allowed class to scaffold bilingual and multilingual learners. Yet is it really best to have EFL classes conducted using L2-based instruction (L2BI)? Should the class allow using code-switching-based instruction (CBI) to help the students? Many studies have been carried out to examine this issue.

Related empirical grounds have been taking shape on how teachers' beliefs and students' preferences on the language used as medium of instructions (Alenezi, 2010; McMillan \& Rivers, 2011; Macaro \& Lee, 2013; Margana, 2013; Wei, 2013; Blackman, 2014; Mareva, 2016; Irawan, 2013; Ekawati, 2014; Haryanto et.al, 2016). Those studies emphasized on the students' and teachers' personal aspects of the effect of preference language as a medium of instructions and the reasons behind them. Those studies were important as an effort to reveal the qualitative side of the use of preference language. To complete those previous studies, this study quantitatively compares the equation on the effectiveness of L2BI with CBI in primary level EFL.

Some other previous studies were only focused on students' overall English proficiency and not in specific language skills (Wong, 2010; Tian \& Macaro, 2012). Even though teaching English means teaching the four skills integrative, it would be better to investigate a specific language skill so that the truth can be elaborated deeper and the result of focuson-skill research can be effectively used to improve certain skill achievement. Furthermore, most of the study involved students in secondary and tertiary levels (Haryanto et.al, 2016; Wong, 2010; Wei, 2013; Tian \& Macaro, 2012; AlKahtany et.al, 2016). Thus, to address these emerging debates on which one is more effective between L2BI and CBI, especially in EFL context, this study compares the effects of L2BI and CSI on primary level EFL speaking classes. Practically, this study gives a new insight for teachers in deciding what language is best used as a medium of instruction.

\section{LITERATURE REVIEW}

English as a Foreign Language (EFL)

Teaching English as a Foreign Language (EFL) differs with teaching English as a Second Language (ESL). One can say English as a Foreign Language (EFL) when English is studied by people who live in a place where English is not the native language. It is in line with Saville-Troike's (2012) idea that said studying a foreign language is to study a language that is not typically or widely spoken or used within the learners' immediate social context (Saville-Troike, 2012 in Williams, 2017, p. 6). In EFL setting, students learn English to be able to use it in communication with other 
English speakers in the world (Harmer, 2007, p. 19). Referring to these terms, most Indonesian students are regarded as EFL learners.

In EFL context, the target language exposures beyond the classroom are insufficient. Though the exposures can be obtained through language clubs, media, books, but they need much effort to do so. The students are also infrequently able to practice the language they learn in their daily life (Brown, 2000, p. 116). Thus typically, in an EFL class, it is not only the lack of exposures in class but also most or all of the students would not naturally use English as a means for communication outside of the controlled environment of the English class.

Based on the definitions above, it can be inferred that teaching English as a Foreign Language (EFL) will be characterized as teaching English in a country in which English is not the native language, with various purposes, and with limited immediate exposure to and practice of the target language outside the classroom. One way to compensate those limitations, the language used by teachers, or the classroom instructions, should be rich of exposure. In other words, teachers should speak authentic communicative English as much as possible. It is in line with Krashen's (2002) idea of teacher talk as one of simple code, which is aimed to help language learners in acquiring second or foreign language. Yet the debate on what language is best used as classroom instruction in EFL setting still has been going on. Hence, it is essential to investigate more on the effectiveness of L2BI with CBI in EFL context, especially when the students are in primary level which is considered lack of background knowledge of English.

Teaching Speaking to Primary Level EFL Students

Primary level students refer to young and young-adult learners. They are in the transition, confusion, selfconsciousness, growing age and changing their bodies and minds (Brown, 2000, p. 92). One of their characteristics as explained by Harmer (2007, p. 83) is always searching for individual identity. Besides, adolescents can also cause discipline problem in the class. The boredom in the classroom is the main reason. Puchta and Schratz (1993) in Harmer (2007, p. 84) say that teenage students are in fact the best language learners when they are engaged to activities which make them out of the boredom and make them enjoy and concentrate in their process of learning such as by using their everyday interests in the instruction.

One of the instructions used by a teacher is known as teacher talk. Teacher talk is particularly important to language teaching (Cook, 2000, p. 144). Based on pedagogical theory, one factor, which determines whether a language class will succeed or not, is the language that teachers use in classrooms. Teacher talk is also regarded as one of the three simple codes, or simpler input in English, proposed by Krashen (2002, p. 120-121). He defines teacher talk as the language used in the classroom that goes along with exercises as well as explanations in some second language and foreign language classrooms, and the language of classroom management. Some studies on teacher talks reveal that teacher talks make up around $70 \%$ of classroom language (Chaudron, 1988; Cook, 2000). Therefore the more effective the teachers' instructions and talks are, the more successful the language learning and teaching will be.

In a speaking class, teacher's instructions play even more important roles. In EFL class, the main exposures are in the classroom so what the teacher says are models for students. Teacher's role in teaching speaking according to Harmer (2007) are as a prompter, a participant, and a feedback provider (p. 347-348). As a prompter, a teacher has to be able to help the students, when they get lost in speaking, by offering discrete suggestions. As a participant, a teacher should be a good animator when asking students to produce language. Then, as a feedback provider means a teacher has a responsibility to respond to the content of speaking activity as well as the language use. Furthermore, a most crucial part of the teacher's job in organizing speaking activity is to make sure that the students understand exactly what they are supposed to do. The primary level EFL students, which have never had enough background knowledge about English, often hesitate to speak. Because of that, their teachers have to make their instructions as effective as possible and also as rich of exposures as possible.

Language Used as a Medium of Instruction

It is already known that there are debates on the language used as a medium of instructions and talks in TEFL. The same debate has also been going on in Indonesia as one country which considers English as a foreign language. Some English teachers in Indonesia prefer to use L2BI. They do so because they want to create as much as possible exposure to English. Some other teachers would like to use code-switching-based instruction. They do so since they want to make it easier for the students to understand what the teachers mean.

In relation to English language teaching (ELT), there are several arguments that are provided by L2BI supporters, or in this case refer to English-Only instruction supporters, in order to offer validity to this approach. All of them are based on the basic premise that the greater the exposure to L2, the greater the possibility of learning of the target language (Ellis, 2005). Some studies then were done related to the learners' and teachers' attitudes towards the use of this type of instruction by the teacher and whether it is effective in making the ELT class succeed (Wong, 2010; McMillan \& Rivers, 2011; Ekawati, 2014; Sa'd \& Qadermazi, 2015). Some of the learners agreed to have such instruction in their classroom as their English proficiency improved. It makes them feel more comfortable in speaking English. Then, the learners in class which has English as the sole medium of instruction had higher English proficiency than those of the more L1tolerant class. Moreover, students enjoyed studying in the monolingual class and supported the use of this instruction in their English classes. Hence, the L2BI used by the teacher is somewhat effective in ELT process.

On the other hand, phenomena of code-switching also occur in English language teaching in EFL classes. One expert that supports code-switching in EFL classes is Guy Cook (2010). He says that a new language is best taught when 
bilingualism is recognized and allowed to be used in the classroom. First language use and translation cannot be separated in learning a new language and both of them give their own advantages to both teachers and learners of a language. Some studies also were done regarding to learners' and teachers' attitudes towards the use of code-switching by English teaching in the ELT process and whether the use of code-switching is effective in the ELT process (Alenezi, 2010; Irawan, 2013; Fareed et.al, 2016; Mareva 2016). The findings show that there are positive attitudes towards teachers' code-switching especially since the learners perceive L1 as a tool to facilitate their learning and to foster their understanding of materials. In other words, ELT process will be effective if the teacher uses code-switching. However, some of the students feel that code-switching by the teachers sometimes restricts their exposure to English.

It can be seen that most of the previous studies only investigated students' and teachers' perceptions towards the language. Meanwhile, the study in this article will reveal the equation of effectiveness of the use of preference language in teaching speaking. It means that the result of students' performance in speaking will be quantitatively studied and statistically analyzed. The findings of previous studies also revealed that level of students also has an effect on teachers' decision of language used for instruction. Unfortunately, most of the previous studies have not investigated the teaching and learning L2 in primary level yet. Most of them were conducted in tertiary level or in a university context. Thus, to be more comprehensive, it will be beneficiary to conduct a research on the language used as the medium of instruction in primary level speaking class, especially Indonesian primary level EFL.

\section{RESEARCH METHOD}

Based on the theories, a quasi-experimental study was developed accordingly. L2BI and CSI were used by the teachers in teaching speaking to the Indonesian primary level EFL students. This study employed pre-test and post-test instruments, involving groups of students in one experimental class and one control class. The experimental class was given different treatment that is the technique in which the teacher uses L2BI in speaking class while the control group was given the common technique applied by most teachers, i.e. a technique in which the teacher uses CBI.

The instruments were oral assessments adapted from Common European Framework of Reference for Languages/ CEFRL issued by Cambridge English Language Assessment (2001). Referring to the CEFR, the seventh graders are classified as A1-A2/ Basic User level. One example of assessments that based on CEFRL can be found Cambridge English Key: Handbook for teachers for exams from 2016 (2016). The test that was carried out was of two types. The first type was information exchange between student-to-student in which they ask and answer questions about factual, personal information using materials have been taught. The contents of the rubrics were grammar and vocabulary, pronunciation, and interactive communication. Then the second type was doing a monologue on certain topics. The contents of the rubrics were grammar and vocabulary as well as pronunciation. Before administered to the participants, the instruments should pass validity and reliability criteria.

The population of this study was the seventh-grade students of a Junior High School in Central Java Province, Indonesia. In order to meet the data requirements to test the effectiveness of L2BI and CBI in teaching speaking to the primary level EFL students, the sampling technique was cluster random sampling. It is the sample selection in which all members of the population are naturally grouped in units (Wiersma and Jurs, 2009, p. 355). The participants were 70 students. The students were randomly divided into two classes as explained previously, 35 students in an experimental group and 35 students in a control group.

The data of the result on post-test was analyzed in some steps. First, it had to pass the normality and homogeneity test. Normality test was used to analyze whether the pre-test and post-test data are in normal distribution or not. Homogeneity test was done to find out whether the variables have an equal variance or not. Then, if the data were proven as normal and homogeny, an ANOVA test will be done. The ANOVA was carried out using SPSS 22 application for Windows. If the result shows $\mathrm{F}>$ Alpha $5 \%$, it means that $\mathrm{H}_{0}$ is rejected and $\mathrm{H}_{\mathrm{a}}$ is accepted. $\mathrm{H}_{0}$ (null hypothesis) is the hypothesis stating that there is no correspondence between independent and dependent variables. Meanwhile, $\mathrm{H}_{\mathrm{a}}$ (alternative hypothesis) is the hypothesis stating that there is a correspondence between independent and dependent variables. In this study, independent variable refers to the language used as a medium of instruction and dependent variable refers to students' speaking achievement. The hypothesis in this study is that use of L2BI is more effective in teaching primary level EFL speaking classes than that of CBI.

\section{RESULTS AND DisCUSSION}

\section{A. Results}

Since this study was quasi-experimental that employs pre and post-test to both experimental and control class, the data then were described based on the pre-test and post-test result.

1. Pre-test Data

The mean, standard deviation, minimum score, and maximum score of pre-test were as follow. 
TABLE 1.

DESCRIPTION OF PRE-TEST SCORE

\begin{tabular}{|l|l|l|}
\hline Group & Analytical Data & Pre-test \\
\hline \multirow{5}{*}{ Experimental } & Mean & 6.34 \\
\cline { 2 - 3 } & Standard Deviation & 1.12 \\
\cline { 2 - 3 } & Minimum & 4.75 \\
\cline { 2 - 3 } Control & Maximum & 9.25 \\
\hline & Mean & 6.11 \\
\cline { 2 - 3 } & Standard Deviation & 1.28 \\
\cline { 2 - 3 } & Minimum & 3.50 \\
\cline { 2 - 3 } & Maximum & 9.25 \\
\hline
\end{tabular}

It is obviously clear from Table 1 that the mean of pre-test scores of the experimental group was 6.34 and the mean of scores of the control group was 6.11. The data then had to fulfill two assumption tests for ANOVA, i.e. normality and homogeneity test. Firstly, normality test was used to analyze whether the data are in normal distribution or not. The test used was Lilliefors Significance Correlation from Kolmogorov-Smirnov with the level of significance is 5\% $(\alpha=$ 0.05). Table 2 below showed the result of normality test.

TABLE 2.

RESULT OF NORMALITY TEST OF PRE-TEST SCORES

\begin{tabular}{|l|l|l|l|}
\hline \multirow{2}{*}{ Group } & Kolmogorov-Smirnov & df & Sig. \\
\cline { 2 - 4 } & Statistic & 35 & 0.20 \\
\hline Experimental & 0.08 & 35 & 0.20 \\
\hline Control & 0.12 & 35 & \\
\hline
\end{tabular}

Table 2 revealed that the value of probability $(p)$ of both classes were higher than $\alpha(0.20>0.05)$. Therefore, the data of pre-test of students' speaking achievement in both experimental and control group were on the normal distribution.

Then, homogeneity of variance test was done to find out whether or not the samples researched have equal variance. The pre-test data were analyzed using one-way ANOVA by seeing the probability (sig) of Levene statistic on the test of homogeneity of variance. Table 3 below presents the result of the test.

TABLE 3.

RESULT OF HOMOGENEITY TEST OF PRE-TEST SCORES

\begin{tabular}{|l|l|l|l|}
\hline Levene Statistic & df1 & df2 & Sig. \\
\hline 0.39 & 1 & 68 & 0.54 \\
\hline
\end{tabular}

The table showed that the value of ' $p$ ' on Levene test is higher than $\alpha(0.54>0.05)$. It means the scores were equal in variance. For this pre-test, a one-way ANOVA was then applied to prove that there is no significant difference between experimental class and control class before employing the treatment. Table 4 below showed the result of the ANOVA analysis.

TABLE 4.

RESULT OF ANOVA TEST OF PRE-TEST SCORE

\begin{tabular}{|l|l|l|l|l|l|}
\hline & Sum of Squares & df & Mean Square & F & Sig. \\
\hline Between Groups & 0.97 & 1 & 0.97 & 0.67 & 0.41 \\
\hline Within Groups & 98.01 & 68 & 1.44 & & \\
\hline Total & 99.02 & 69 & & & \\
\hline
\end{tabular}

The table revealed that the value of probability $p$ is higher than $\alpha(0.41>0.05)$. It means that there was no significant difference between experimental class and control class before employing the treatment. It indicated that before the treatment, all the samples were in the same level of English speaking proficiency.

2. Post-test Data

The descriptive statistics including mean, standard deviation, minimum, and maximum scores of post-test data were shown in Table 5 below.

TABLE 5.

DESCRIPTION OF POST-TEST SCORE

\begin{tabular}{|l|l|l|}
\hline Group & Analytical Data & Post-test \\
\hline \multirow{5}{*}{ Experimental } & Mean & 8.79 \\
\cline { 2 - 3 } & Standard Deviation & 0.54 \\
\cline { 2 - 3 } & Minimum & 7.50 \\
\cline { 2 - 3 } & Maximum & 9.75 \\
\hline \multirow{5}{*}{ Control } & Mean & 8.49 \\
\cline { 2 - 3 } & Standard Deviation & 0.68 \\
\cline { 2 - 3 } & Minimum & 7.00 \\
\cline { 2 - 3 } & Maximum & 9.75 \\
\hline
\end{tabular}


It is shown in Table 5 that the mean of post-test scores of the experimental group was 8.79 and the mean of scores of the control group was 8.49. To pass two assumptions of ANOVA, the data then also had to be tested for their normality and homogeneity. First, normality test was used to analyze whether the data are in normal distribution or not. The test used was Lilliefors Significance Correlation from Kolmogorov-Smirnov with the level of significance is 5\% $(\alpha=0.05)$. Table 6 below showed the result of normality test.

TABLE 6.

RESULT OF NORMALITY TEST OF POST-TEST SCORES

\begin{tabular}{|l|l|l|l|}
\hline \multirow{2}{*}{ Group } & Kolmogorov-Smirnov & Sig. \\
\cline { 2 - 4 } & Statistic & df & 0.08 \\
\hline Experimental & 0.14 & 35 & 0.20 \\
\hline Control & 0.12 & 35 & \\
\hline
\end{tabular}

Table 6 showed that the value of probability (p) of the experimental class was higher than $\alpha(0.08>0.05)$ and the value of probability $(p)$ of control class were also higher than $\alpha(0.20>0.05)$. Therefore, the data of post-test of students' speaking achievement in both experimental and control group were on the normal distribution.

Then, homogeneity of variance test was done to find out whether or not the samples researched have an equal variance. The post-test data were analyzed using one-way ANOVA by seeing the probability (sig) of Levene statistic on the test of homogeneity of variance. Table 7 below presented the result of the test.

TABLE 7.

RESULT OF HOMOGENEITY TEST OF POST-TEST SCORES

\begin{tabular}{|l|l|l|l|}
\hline Revene Statistic & df1 & df2 & Sig. \\
\hline 2.19 & 1 & 68 & 0.14 \\
\hline
\end{tabular}

The table showed that the value of ' $p$ ' on Levene test was higher than $\alpha(0.14>0.05)$. It denoted the variant of the scores are equal. For the final analysis of post-test data, a one-way ANOVA was then applied to prove that there is a significant difference between experimental class and control class after the treatment. Table 8 below showed the result of the analysis.

TABLE 8.

RESULT OF ANOVA TEST OF POST-TEST SCORE

\begin{tabular}{|l|l|l|l|l|l|}
\hline & Sum of Squares & df & Mean Square & F & Sig. \\
\hline Between Groups & 1.57 & 1 & 1.57 & 4.17 & 0.04 \\
\hline Within Groups & 25.63 & 68 & 0.37 & & \\
\hline Total & 27.21 & 69 & & & \\
\hline
\end{tabular}

The table revealed that the value of probability $p$ is lower than $\alpha(0.04<0.05)$. It meant that there was a significant difference between experimental class and control class after the treatment. It could be inferred that teaching technique which employs L2-based instruction (L2BI) made students gain better speaking achievement than that of common technique which employs code-switching-based instruction (CBI).

\section{B. Discussion}

As shown in Table 8, there are significant statistical differences, which $p$ is lower than $\alpha(0.04<0.05)$, between the mean of speaking achievement in post-test of the experimental group over that of the control group. It differs with the result of speaking achievement in pre-test $(\alpha=0.41)$. This can be attributed to L2BI which is employed to teach students in the experimental group. L2BI positively improves the speaking achievement of students in the experimental class. Students who belong to this class are characterized as more active participants. In speaking class activities, they are willing to speak English more rather than their native language while students in control group are still feeling more comfortable to speak in their L1. It absolutely has an impact on their post-test achievement. Students in experimental class who used to speak English during the learning process can achieve better achievement. It therefore supports the notion of learning as a habitual action which requires more practices to make perfect.

Students who belong to the experimental class are also characterized as more positive learners. They pay more attention to what their teacher says, try harder to listen how to pronounce the word correctly and make more effort to comprehend the meaning of their teacher's utterances. Since teacher in the control group is allowed to switch between L2 and L1, the students pay less attention to the English pronunciation and make less effort to comprehend their teacher's talks. They, in fact, are more talkative but in more 'negative' term, that is 'speak more but not speak English'. It corresponds to the result of post-test. After the treatment, students in the experimental class can use more varied vocabulary with better pronunciation while students in control class often are found repeating mispronunciation. As a result, students in experimental class gain better achievement than students in control class.

The result of this study supports what some previous studies related to use of L2BI have been revealed. Wei (2013) and Haryanto et.al (2016) both find that L2BI which is employed in tertiary level EFL students somehow make students progress in English listening and speaking proficiency. On the contrary, in Vietnam EFL context, Hoang, Jang, and Yang's (2010) research reveals that the English-Only policy failed to assure the majority (around 70\%) of the students' 
sufficient understanding of the lesson. It is because, in the Vietnamese educational situations, the implementation of L2BI has been constrained by some factors. There are insufficient classroom resources, teachers' limited English abilities, teaching methods, students' low level of English competence, motivation, and autonomy. For the Indonesian primary EFL level, it is also true that the teachers have to make more effort to make their instructions clear and effective as well, regarding students in the primary level have only limited background English knowledge. The teachers must be more creative in explaining the materials, must have sufficient vocabulary, must have the ability to paraphrase, as well as must be able to use teachers' talk as one of simple code that promotes the use of authentic language to reach communicative language teaching context.

\section{CONClusions AND SugGestions}

Based on the findings of the collected data and its interpretation, it can be concluded that use of L2BI is more effective in teaching primary level EFL speaking classes than that of CBI $(p<0.05)$. It means that speaking achievement of primary level EFL students can be better if the teacher employs L2BI during the teaching process. The use of such instruction makes students more eager to speak in L2, pay more attention to what their teacher says, try harder to listen how to pronounce the word correctly, and make more effort to comprehend the meaning of their teacher's utterances.

Therefore, L2BI shall be used in primary level EFL speaking class. It is not an easy job, especially in EFL context where the English teachers are not native English. The teachers must make more effort to make their instructions clear, correct, and effective as well. The teachers must be more creative in explaining the materials, must have sufficient vocabulary, must have the ability to paraphrase, as well as must be able to use teachers' talk as one of simple code that promotes the use of authentic language to reach communicative language teaching context. Nevertheless, it is still possible to do. Teachers can always learn and train themselves to improve their English and teaching competencies. It would be better if government support this effort by conducting relevant trainings for the teachers.

\section{REFERENCES}

[1] Alenezi, A. A. (2010). Students' language attitude towards using code-switching as a medium of instruction in the college of health sciences: An exploratory study. ARECLS, 7, 1-22.

[2] Al-Kahtany, A. H., S.M.G. Faruk, A. W. Q. Al Zumor. (2016). English as the medium of instruction in Saudi higher education: Necessity or Hegemony? Journal of Language Teaching and Research, 7(1), 49-58.

[3] Blackman, N. (2014). EFL teachers' perceptions on the use of L1 in a primary and secondary classroom in Belarus. British Council ELT Master's Dissertation Awards: Commendation.

[4] Brown, H. D. (2000). Teaching by principles: An interactive approach to language pedagogy (2 ${ }^{\text {nd }}$.ed.). New York: Longman.

[5] Cambridge English key: Handbook for teachers for exams from 2016. (2016). Cambridge: Cambridge English Language Assessment.

[6] Chaudron, C. (1988). Second language classrooms: research on teaching and learning. Cambridge: Cambridge University Press.

[7] Common European Framework of Reference for Languages: Learning, Teaching, Assessment. (2001). Cambridge: Cambridge University Press.

[8] Cook, G. (2010). Translation in language teaching. Oxford: Oxford University Press.

[9] Cook, V. (2000). Second language learning and language teaching (2nd edition). Beijing: Foreign Language Teaching and Research Press.

[10] Ekawati, S.M. (2014). Students attitude toward monolingual approach in English classes at SMA Lab Salatiga. Unpublished thesis, Satya Wacana Christian University, Salatiga, Indonesia.

[11] Ellis, R. (2005). Instructed second language acquisition: a literature review. Auckland: Auckland UniServices Limited.

[12] Fareed, M., S. Humayun, \& H. Akhtar. (2016). English language teachers' code-switching in class: ESL learners' perceptions. Journal of Education and Social Sciences, 4(1), 1-11.

[13] Harmer, J. (2007). The practice of English language teaching ( $4^{\text {th }}$.ed.). Harlow, England: Longman.

[14] Haryanto, E., U. Sulistiyo, M. Khairani, et.al. (2016). Indonesian or English? EFL student teachers' preference and perception on the language use in the classroom. Indonesian Journal of English Education (IJEE), 3(1), 46-59.

[15] Hoang, N. T. B., S. H. Jang, Y. Yang. (2010). English-Only classroom: ideology versus reality. Paper presented at the 2010 AARE Annual Conference, Melbourne. http:// http://aare.edu.au/data/publications/2010/1755HoangJangYang.pdf (access 19/03/2018).

[16] Irawan, H. (2013). Students' perceptions toward the use of Bahasa Indonesia in teaching English. Unpublished thesis, Satya Wacana Christian University, Salatiga, Indonesia.

[17] Krashen, S. D. (2002). Second Language Acquisition and Second Language Learning (internet ed.). Prentice-Hall International.

[18] Macaro, E. \& J. H. Lee. (2013). Teacher language background, code-switching, and English-only instruction: Does age make a difference to learners' attitudes? TESOL Quarterly, 47(4), 717-742.

[19] Margana. (2013). Alih Kode dalam proses pembelajaran bahasa Inggris di SMA. LITERA Jurnal Penelitian Bahasa, Sastra, dan Pengajarannya, 12.1, 39-52.

[20] McMillan, B. A. \& D.J. Rivers. (2011). The practice of policy: Teacher attitudes toward English-Only. Science Direct, 39, 251263.

[21] Mareva, R. (2016). Learners' code-switching in English as a Second Language (ESL) lessons: perspectives of four secondary school teachers in Zimbabwe. IRA International Journal of Education and Multidisciplinary Studies, 4(1), 71-90. 
[22] Sa'd, S. H. T. \& Z. Qadermazi. (2015). L1 use in EFL classes with English-Only policy: Insight from triangulated data. CEPS Journal, 5(2), 159-175.

[23] Tian, L \& L. Macaro. (2012). Comparing the effect of teacher code-switching with English-only explanations on the vocabulary acquisition of Chinese university students: A lexical focus on form study. Language Teaching Research, 16(3), 367-391.

[24] Wei, D.D. (2013). The implementation of English-Only policy in the tertiary level EFL context in Taiwan. Indonesian Journal of Applied Linguistics, 2(2), 187-198.

[25] Wiersma, W. \& S. G. Jurs. (2009). Research Methods in Education ( $9^{\text {th }}$.ed.). Boston: Pearson Education.

[26] Williams, C.H. (2017). Teaching English in East Asia: A teacher's guide to Chinese, Japanese, and Korean learners. Singapore: Springer Nature.

[27] Wong, R.M.H. (2010). The effectiveness of using English as the sole medium of instruction in English classes: Student responses and improved English proficiency. Porta Linguarum, 13, 119-130.

Dwi Ide Rahayu is an English teacher at a Junior High School in Central Java province, Indonesia. She graduated her undergraduate study from English Education Department, Yogyakarta State University, Indonesia. She is currently pursuing her master degree in Applied Linguistic department, Post Graduate Program, Yogyakarta State University, Indonesia. Her study is fully funded by a scholarship from Indonesia Endowment Fund for Education (Lembaga Pengelola Dana Pendidikan), a scholarship by the Indonesian government. Her areas of interest include teaching English to speakers of other languages (TESOL) and English teaching and learning for young-adult learners.

Margana is a professor at Yogyakarta State University, Indonesia. He received his master degree in Linguistics from Gadjah Mada University, Indonesia and in Applied Linguistics from the University of Newcastle. He received his Ph.D in Linguistics from Gadjah Mada University, Indonesia. Currently, he is the first vice rector of Yogyakarta State University. His research interests are Sociolinguistics related to bilingualism and code-switching, Psycholinguistics, and English language teaching and learning. 